\title{
IRI performance models for recently constructed low and medium-traffic two lane roads of the province of Biscay
}

\author{
Heriberto Pérez-Acebo \\ Assistant Professor, Mechanical Engineering Department, University of the Basque \\ Country, UPV/EHU, Spain \\ Hernán Gonzalo-Orden \\ Professor, Civil Engineering Department, University of Burgos, Spain
}

\section{SUMMARY}

Reliable pavement prediction models are needed for pavement management systems (PMS), as they are a key component to forecast future conditions of the pavement and to prioritize maintenance, rehabilitation, and reconstruction strategies. The International Roughness Index (IRI) is the most used parameter worldwide for calibrating pavement roughness and measures reasonably the ride comfort perceived by occupants of passenger cars. The Regional Government of Biscay also collects this value on the road network under its control. These surveys are carried out regularly in the XXI century. Several IRI performance models have been proposed by different authors and administrations, varying greatly in their comprehensiveness, the ability to predict performance with accuracy and input data requirements. The aim of this paper is to develop a roughness performance model for Biscay's roads, based on available IRI data, taking into account heavy traffic volume and the age of pavement. Local characteristics as climate conditions and average rainfall are not considered. IRI performance models have been suggested for regional two lane highways with low and medium heavy traffic constructed in the last 20 years in the province of Biscay, with no treatments during their life. They can be applied for flexible pavements, but no logical coherent results have been concluded for semi-rigid pavements.

\section{INTRODUCTION}

Pavement management systems (PMS) collect and monitor current pavement information, forecast future conditions, and prioritize alternative reconstruction, rehabilitation, and maintenance strategies to achieve a steady state of system preservation at a predetermined level of performance. Such systems are strongly dependent upon the confidence level of the prediction of future pavement condition. Therefore, the pavement performance model is a key component of the PMS to predict the future performance of pavements. It is also essential for optimizing maintenance and rehabilitation strategies over a planning horizon. Future performance of pavements depends on existing pavement condition and other variables controlling deterioration such as truck traffic volume, climate and pavement structure. By reducing the prediction error of pavement deterioration, administrations can obtain significant budget savings through timely intervention (Prozzi and Madanat, 2004). 
The currently available performance prediction models can be broadly classified into two groups: empirical and mechanistic-empirical models. Those models vary enormously in their comprehensiveness, their ability to predict performance with reasonable accuracy and input data requirement. Despite the enormous efforts expended on prediction methods by the engineering field, it is still difficult to make accurate predictions of pavement life (Molenaar 2003). This is due to the fact that it is very difficult to predict variations of contributing factors that influence pavement performance. By including roadway pavement performance variables, such as construction techniques, traffic, and weather or aging, modeling becomes even more complex (Meegoda and Gao, 2014).

Pavement surface roughness is one of the most commonly used measures to gage road users' level of satisfaction, while at the same time provides an assessment of roadway conditions to road owners. Many highway agencies, included the Regional Government of Biscay, conduct automated and regular roughness measurements in terms of International Roughness Index (IRI). IRI was developed in 1986 using the results of the International Road Roughness Experiment performed in Brazil in 1982 (Sayers et al. 1986). Since then, the IRI has become a well-recognized standard for the measurement of road roughness, being stable over time and transferable throughout the world. Technically, the IRI is a mathematical representation of the accumulated suspension stroke of a vehicle, divided by the distance that it travels during the same period and defined by applying the algorithm proposed by Sayers (1995). The IRI is calculated from the measured longitudinal profile with the use of a quarter car simulation along a single wheel path. Normally employed units are $\mathrm{mm} / \mathrm{m}$ or $\mathrm{m} / \mathrm{km}$.

The popularity of the IRI has increased over the years and now it becomes a dominant criterion in describing pavement performance, and it has been also directly related to the cost of vehicle operation (Archondo-Callao and Faiz 1994) Roughness was found to be highly correlated with present serviceability rating (PSR) and the present serviceability index (PSI) (Haas et al. 1994). Hence, it is feasible to use IRI as a pavement performance index. When it is difficult to collect distress measurement and imaging with limited resources, it is reasonable to rely only on the IRI to establish road sections needing maintenance or improvement.

The progression of roughness with time is a complex phenomenon. Paterson (1987) showed that composite distress depends on deformation due to traffic loading and rut depth variation, surface defects form cracking, potholes and patching and a combination of aging and environmental factors. Other authors estimated different predictors for IRI progression: previous year IRI value, cumulative number of equivalent single axle loads (ESALs), base thickness, total thickness of Asphalt Concrete (AC), minimum temperature in the coldest month and annual precipitation (Madanat et al. 2005); hot mix asphalt (HMA) layer thickness, project location (urban or rural), base type, HMA classification and pavement length (Wen 2011). Perera and Kohn (2001) using the long-term pavement performance (LTPP) data showed that, although design and rehabilitation parameters, climatic conditions, 
traffic levels, material properties and extent are major factors causing pavement smoothness changes; the effect of the subgrade and climatic conditions at a site might not been seen if a pavement is designed "correctly" for these parameters.

The Guide for Mechanistic-Empirical Design of New and Rehabilitated Pavement Structures (NCHRP 2004) proposed IRI individual models for new AC pavement with bound base material, Cement Stabilized Base (CSB); for new AC sections with unbound General Base Course (GBC) and for overlaid pavement sections with GBC. A summary of the input variables in each category included in the 3 models is listed in Table 1.

\begin{tabular}{|c|c|c|c|c|}
\hline \multirow{2}{*}{ Category } & \multicolumn{3}{|c|}{$\begin{array}{c}\text { Variables in Guide for Mechanistic-Empirical Design of } \\
\text { New and Rehabilitated Pavement Structures }\end{array}$} & \multirow{2}{*}{$\begin{array}{c}\text { Variables in HDM Model } \\
\text { New and Overlaid } \\
\text { (Any Base) } \\
\end{array}$} \\
\hline & New AC (CBS) & New AC (GBC) & $\begin{array}{l}\text { Overlaid } \\
\text { (GBC) }\end{array}$ & \\
\hline \multirow{4}{*}{ Structure } & $I R I_{0}$ & $I R I_{0}$ & $I R I_{0}$ & $I R I_{0}$ \\
\hline & - & - & - & Structural Number \\
\hline & - & Age & Age & $\begin{array}{l}\text { Age since last major } \\
\text { Treatment }\end{array}$ \\
\hline & - & - & - & $\begin{array}{l}\text { Thickness of old and new AC } \\
\text { Layers }\end{array}$ \\
\hline \multirow{3}{*}{ Subgrade } & - & $\%$ Passing $0,075 \mathrm{~mm}$ sieve & - & - \\
\hline & - & $\%$ Passing $0,02 \mathrm{~mm}$ sieve & - & - \\
\hline & - & Plasticity Index & - & - \\
\hline \multirow{3}{*}{ Climate } & - & FI & FI & \multirow{3}{*}{$\begin{array}{l}\text { Climatic factor based on } \\
\text { Ambient Temperature and } \\
\text { Moisture Index }\end{array}$} \\
\hline & - & SD of Monthly Rainfall & - & \\
\hline & - & Average Annual Rainfall & - & \\
\hline Traffic & - & - & - & $\begin{array}{l}\text { Annual number of equivalent } \\
\text { standard axles (ESAL) }\end{array}$ \\
\hline \multirow{5}{*}{ Distresses } & Transversal Cracking & Trans. Cracking & $\begin{array}{l}\text { Trans. } \\
\text { cracking } \\
\text { spacing }\end{array}$ & $\begin{array}{l}\text { Cracking area of existing } \\
\text { layer }\end{array}$ \\
\hline & Fatigue Crack & Fatigue Crack & Fatigue Crack & Cracking area of old surfacing \\
\hline & Block Crack area & Block Crack area & Patches area & Potholing \\
\hline & $\begin{array}{l}\text { Sealed Crack outside } \\
\text { the wheel path }\end{array}$ & $\begin{array}{l}\text { Sealed Crack outside the } \\
\text { wheel path }\end{array}$ & $\begin{array}{l}\text { Longitudinal } \\
\text { cracks }\end{array}$ & - \\
\hline & SD of Rut Depth & COV of Rut Depth & Pothole Area & SD of Rut Depth \\
\hline
\end{tabular}

Table 1 - Summary of the variables in the Guide for Mechanistic-Empirical Design of New and Rehabilitated Pavement Structures and in the HDM IRI prediction models

The Mechanistic-Empirical Pavement Design Guide (MEPDG) (AASHTO 2008) proposes smoothness degradation models, embedded in AASHTOWare Pavement ME Design (AASHTO 2011) to predict the IRI over time for Hot Mix Asphalt (HMA) and HMA Overlays of Flexile Pavement (Equation 1) and HMA Overlays of Rigid Pavements (Equation 2). In both equations the site factor value is used, which is defined by Equation 3. Explanations of each variable in Equations (1), (2) and (3) are shown in Table 2.

$$
I R I=I R I_{0}+40,0 \cdot R D+0,40 \cdot F C_{\text {Total }}+0,008 \cdot T C+0,015 \cdot S F
$$




$$
\begin{gathered}
I R I=I R I_{0}+40,8 \cdot R D+0,575 \cdot F C_{\text {Total }}+0,0014 \cdot T C+0,00825 \cdot S F \\
S F=A g e^{1,5}\left[\ln \left[(P c+1)(F I+1) p_{02}\right]\right]+\left[\ln \left[(P c+1)(P I+1) p_{200}\right]\right]
\end{gathered}
$$

\begin{tabular}{|l|l|}
\hline Parameter & Explanation \\
\hline$I R I_{0}$ & Initial IRI after construction, in./mi \\
\hline$F C_{\text {Total }}$ & $\begin{array}{l}\text { Area of fatigue cracking (combined alligator, longitudinal and reflection cracking in the } \\
\text { wheel path), percent of total area }\end{array}$ \\
\hline$T C$ & $\begin{array}{l}\text { Length of transverse cracking (including the reflection of transverse cracking in existing } \\
\text { HMA pavements), } \mathrm{ft} / \mathrm{mi}\end{array}$ \\
\hline$R D$ & Average rut depth, in. \\
\hline$A g e$ & Pavement age, years \\
\hline$P I$ & Percent plasticity index of the soils \\
\hline$F I$ & Average annual freezing index, ${ }^{\circ} \mathrm{F}$ days \\
\hline$P c$ & Average annual precipitation or rainfall, in \\
\hline$P_{02}$ & Percent passing the $0,02 \mathrm{~mm}$ sieve \\
\hline$P_{200}$ & Percent passing the $0,075 \mathrm{~mm}$ sieve \\
\hline
\end{tabular}

Table 2 - Variables used in Equations (1), (2) and (3)

The MEPDG does not include semi-rigid pavements, where HMA is placed over cementitious stabilized materials, as lime, lime-fly ash and Portland cement stabilizers. Hence, they are not recommended for analyzing using AASHTOWare Pavement ME Design until this kind of pavement has been calibrated. Another IRI model that has gained popularity in several countries over the past few decades is the Highway Development and Management (HDM) model (Odoki and Kerali 2000). It can be utilized to predict pavement IRI progression by considering the effects of pavement structure, climatic and environmental conditions, traffic loading and some types of distresses (Table 1).

Although a Mechanistic-Empirical (ME) model is desirable due to its capability to incorporate many potential affecting factors into the model, it is still not fully implemented by all the highways agencies in their PMS due to the complexity in development and calibration of the model. Moreover, many parameters data must be collected in order to be able to calibrate the proposed models to the local characteristics. This is the case of the Regional Government of Biscay, which collected pavement parameters into its Pavement Management System. However, the collected data do not include all the used variables in described models. Hence, in this paper IRI regression models are analyzed and proposed for the recently constructed low and medium-traffic two lane roads of Biscay, using the available data collected by the Regional Government of Biscay in the XXI century.

\section{DATABASE DESCRIPTION}




\subsection{New Pavement Management System on Biscay}

The Regional Government of Biscay has conducted some data collection during the XX century so as to establish a Pavement Management System (PMS) for the entire road network. The main goal of road parameter collection is to better know the present state of pavements and to develop an integral PMS, able to forecast maintenance or rehabilitation needs in future years. So, it will be eliminated the subjective decision of road maintenance, rehabilitation and reconstruction, which was based on experts' opinions. Hence, a more efficient management system will be carried out, able to prioritize budget allocation.

\subsection{Localization of Biscay}

Biscay is located in the north of Spain and is one the 3 provinces in which the autonomous region of the Basque Country is divided. It has an extension of $2.217 \mathrm{~km}^{2}$ and a population of 1.159 .639 inhabitants in 2014, with a density of 520 people $/ \mathrm{km}^{2}$. The climate is oceanic, with high precipitation all year round and moderate temperatures. Temperatures are more extreme in the higher lands of inner Biscay, where snow is more common during winter. The average high temperature in main city Bilbao is between $13{ }^{\circ} \mathrm{C}$ in January and $26{ }^{\circ} \mathrm{C}$ in August. Due to the special status of the Basque Government and the 3 provinces, competences about roads has transferred to each provinces, so that is the Regional Government of Biscay is able to plan, project, modify, construct, maintain, finance, use and run all the highways in the territory. Apart from a freeway concession given by the Central Government and a port road depending on the Port Authority, a road network of more than $1.200 \mathrm{~km}$ is managed by the Regional Government of Biscay (Table 3).

\begin{tabular}{|c|c|c|c|c|c|c|c|}
\hline Ownership & Road Category & $\begin{array}{c}\text { Paying } \\
\text { Freeways } \\
(\mathbf{k m})\end{array}$ & $\begin{array}{c}\text { Not paying } \\
\text { freeways } \\
(\mathbf{k m})\end{array}$ & $\begin{array}{c}\text { Freeways } \\
\left(2^{\text {nd }} \text { cat }\right) \\
(\mathbf{k m})\end{array}$ & $\begin{array}{c}\text { Multilane } \\
\text { highways } \\
(\mathbf{k m})\end{array}$ & $\begin{array}{c}\text { Conventional } \\
\text { roads } \\
(\mathbf{k m})\end{array}$ & $\begin{array}{l}\text { Total } \\
(\mathbf{k m})\end{array}$ \\
\hline \multirow{5}{*}{$\begin{array}{c}\text { Regional } \\
\text { Government } \\
\text { of Biscay }\end{array}$} & National & 46,531 & 30,009 & 27,295 & 13,854 & 106,794 & 224,483 \\
\hline & Preferential & & & 39,437 & 19,470 & 151,507 & 210,477 \\
\hline & Complementary & & & & 4,803 & 17,950 & 22,753 \\
\hline & Regional road & & & & 1,070 & 208,847 & 209,917 \\
\hline & Local road & & & & 1,217 & 609,685 & 610,902 \\
\hline TOTAL & & & & & & & \begin{tabular}{|l|}
$1.278,532$ \\
\end{tabular} \\
\hline Central Gov. & National & 22,350 & & & & & 22,350 \\
\hline Port Authority & Complementary & 6,130 & & & & & 6,130 \\
\hline TOTAL & & & & & & & 28,480 \\
\hline
\end{tabular}

Table 3 - Road network of Biscay in each category (km)

Roads and streets owned by municipalities are not included in Table 3. These roads and streets are managed and maintained by town councils by means of local budgets.

\subsection{Data collection}

Data collections were conducted by the Regional Government of Biscay in the following years: 2000, 2004, 2007 and 2011-2012. At present, some new campaigns are planned for 
2016. In those surveys geometric and pavement state parameters were collected. Related to road geometry, all factors were measured: lane width, number of lanes, shoulder width, platform width, median width, horizontal curve radii, vertical grades, superelevation, sight distance and inverse sight distance, UTM position and orientation every $10 \mathrm{~m}$. Pavement state parameters included in the data collection are IRI, friction coefficient (by means of the SideForce Coefficient Road Inventory Machine, SCRIM), texture and deflection. All this values with the historic information of every highway in Biscay is being stored in new software called State Agenda (Agenda de Estado). Information is available for people in charge of road maintenance. All the construction, maintenance and rehabilitation projects carried out in a highway are listed, being possible to know the sequence of work in every PK of the road network. Moreover, traffic data, such as Average Daily Traffic (ADT) volume and heavy vehicle ADT volume are also integrated in the software (Figure 1). It also includes SIG position of every road stretch.

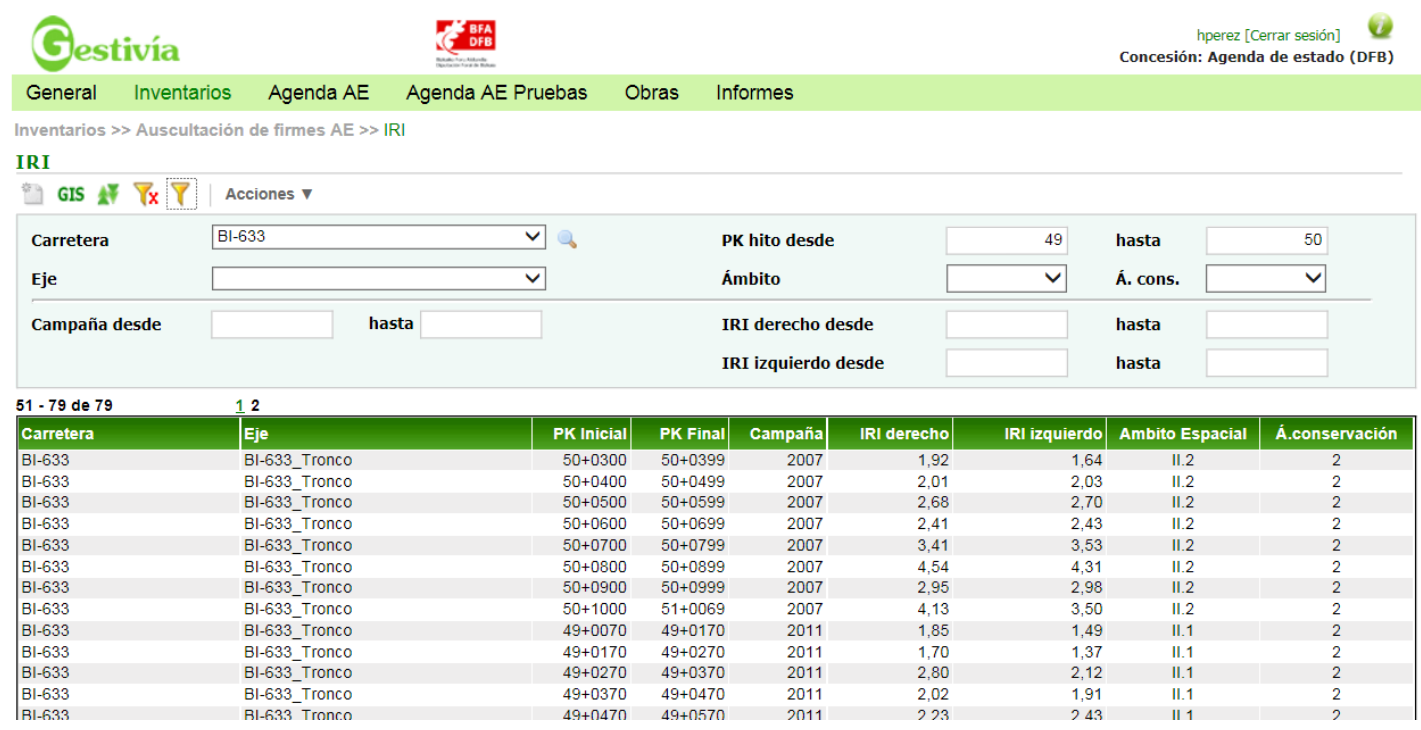

Fig. 1 - State Agenda software image (IRI data from BI-633 highway)

\section{DATA PROCESSING}

\subsection{Selected highways}

Recently constructed highways in Biscay were selected to this analysis. As the available parameters were obtained in 2000, 2004, 2007 and 2011, new design roads were chosen, in order to avoid interferences from previous structures. During the last 20 years, apart from road improvement design in some roads, completely newly projected highways and freeways have been constructed by the Regional Government of Biscay. Normally they are alternative roads to the ones that cross cities and villages, a by-pass road, aiming to take the traffic away from the city centre. New corridors, including some new freeways, have been also constructed, but they have not been considered in this research. The selected ten highways are presented in Table 4. 


\begin{tabular}{|c|c|c|c|c|c|c|c|c|}
\hline$\underset{\text { Road }}{\text { denomination }}$ & Road category & Place & Initial PK & Final PK & $\begin{array}{c}\text { Length } \\
\text { (km) }\end{array}$ & $\begin{array}{c}\text { Construction } \\
\text { year }\end{array}$ & \begin{tabular}{|c|} 
ADDT \\
$(2014)$ \\
(veh/day) \\
\end{tabular} & $\begin{array}{c}\text { Heavy } \\
\text { traffic } \\
(\%) \\
\end{array}$ \\
\hline BI-2405 & Regional & Lekeitio & $65+0500$ & $67+0090$ & 1,590 & $23 / 10 / 2009$ & 2.987 & 6,2 \\
\hline BI-635 & Preferential & Gernika & $34+0100$ & $37+0490$ & 3,390 & $01 / 10 / 2003$ & 10.736 & 4,7 \\
\hline BI-2522 & Regional & Orozko & $23+0800$ & $25+0100$ & 1,300 & $01 / 06 / 1997$ & 1.775 & 10,6 \\
\hline BI-625 & Preferential & Orduña & $351+0390$ & $352+0600$ & 1,210 & $01 / 10 / 1994$ & 4852 & 6,2 \\
\hline \begin{tabular}{|l|} 
BI-732 \\
\end{tabular} & Complementary & Durango & $50+0390$ & $51+0100$ & 0,710 & $01 / 10 / 2005$ & 15.840 & 10,3 \\
\hline $\begin{array}{l}\mathrm{N}-240 \\
\end{array}$ & National & Igorre & $19+0500$ & $23+0600$ & 4,100 & $01 / 11 / 2009$ & 11.045 & 16,3 \\
\hline N-636 & National & Elorrio & $40+0500$ & $44+0300$ & 3,800 & $16 / 04 / 1999$ & 5.635 & 17,6 \\
\hline BI-633 & Preferential & Ondarroa & $57+0000$ & $59+0545$ & 2,545 & $07 / 08 / 2002$ & 5.496 & 7,0 \\
\hline $\mathrm{N}-240$ & National & Zeanuri & $30+0300$ & $32+0000$ & 1,700 & $19 / 07 / 2002$ & 5.326 & 32,0 \\
\hline BI-633 & Preferential & Markina & $49+0200$ & $50+0550$ & 1,350 & 08/01/2003 & 8.045 & 9,5 \\
\hline \multicolumn{5}{|l|}{\begin{tabular}{|l} 
TOTAL \\
\end{tabular}} & 21,695 & & & \\
\hline
\end{tabular}

\section{Table 4 - Data from selected roads for the analysis}

The selected roads range from regional category to national category. All of them are two lane highways, except from 2 kilometres in N-636 road, which has 2 lanes in each direction. They have constructed between 1994, the oldest one, and 2009, the most recent one. Right and left lanes have been considered in each highway. The pavement structure section in each road was maintained all the stretch long, so it is constant between indicated PKs. Table 5 shows the composition of each pavement section.

\begin{tabular}{|c|c|c|c|c|c|c|c|c|c|c|c|c|}
\hline \multirow{3}{*}{$\begin{array}{c}\text { Road } \\
\text { denomi } \\
- \\
\text { nation }\end{array}$} & \multicolumn{7}{|c|}{ HMA layers } & \multicolumn{5}{|c|}{ Base + Sub-base } \\
\hline & \multicolumn{2}{|c|}{ Surface } & \multicolumn{2}{|c|}{ Intermediate } & \multicolumn{2}{|c|}{ Base } & \multirow[b]{2}{*}{ Total } & \multicolumn{2}{|c|}{ Base layer } & \multirow[b]{2}{*}{$\mathbf{c m}$} & \multicolumn{2}{|c|}{ Sub base layer } \\
\hline & Type & $\mathbf{c m}$ & Type & $\mathbf{c m}$ & Type & $\mathbf{c m}$ & & Type & Material & & Material & $\mathbf{c m}$ \\
\hline BI-2405 & S-12 & 5 & & & $\mathrm{~S}-20$ & 8 & 13 & $\begin{array}{c}\text { Cementitious } \\
\text { materials }\end{array}$ & $\begin{array}{l}\text { Portland cement } \\
+ \text { gravel }\end{array}$ & 30 & & \\
\hline BI-635 & $\mathrm{F}-10$ & 4 & $\mathrm{~S}-12$ & 4 & $\mathrm{~S}-12$ & 4 & 12 & $\begin{array}{c}\text { Cementitious } \\
\text { materials }\end{array}$ & Slag + gravel & 28 & & \\
\hline BI-2522 & S-12 & 6 & & & G-20 & 7 & 13 & $\begin{array}{c}\text { Cementitious } \\
\text { materials }\end{array}$ & Slag + gravel & 25 & $\begin{array}{c}\text { Crushed } \\
\text { stone }\end{array}$ & 20 \\
\hline BI-625 & S-12 & 6 & & & G-25 & 11 & 17 & $\begin{array}{c}\text { Unbound } \\
\text { aggregate base }\end{array}$ & Crushed stone & 25 & & \\
\hline BI-732 & F-10 & 3 & & & S-20 & 12 & 15 & $\begin{array}{c}\text { Cementitious } \\
\text { materials }\end{array}$ & Slag + gravel & 30 & $\begin{array}{c}\text { Crushed } \\
\text { stone }\end{array}$ & 20 \\
\hline $\mathrm{N}-240$ & $\mathrm{~F}-10$ & 3 & S-20 & 5 & G-20 & 12 & 20 & $\begin{array}{c}\text { Cementitious } \\
\text { materials }\end{array}$ & $\begin{array}{c}\text { Portland cement } \\
\text { +soil-aggregate }\end{array}$ & 25 & & \\
\hline N-636 & $\mathrm{F}-10$ & 3,5 & $\mathrm{~S}-12$ & 4 & G-20 & 12 & 19,5 & $\begin{array}{c}\text { Unbound } \\
\text { aggregate base }\end{array}$ & Crushed stone & 25 & & \\
\hline BI-633 & S-12 & 6 & & & G-20 & 11 & 17 & $\begin{array}{c}\text { Unbound } \\
\text { aggregate base }\end{array}$ & Crushed stone & 25 & & \\
\hline $\mathrm{N}-240$ & PA-12 & 4 & S-20 & 8 & G-25 & 18 & 30 & $\begin{array}{c}\text { Unbound } \\
\text { aggregate base }\end{array}$ & Crushed stone & 25 & & \\
\hline BI-633 & S-12 & 6 & & & G-20 & 11 & 17 & $\begin{array}{c}\text { Unbound } \\
\text { aggregate base }\end{array}$ & Crushed stone & 25 & & \\
\hline
\end{tabular}

\section{Table 5 - Materials used in each highway section}

There are conventional flexible pavements with unbound aggregate base and semi-rigid pavements with cementitious stabilized base, including Portland cement + gravel, Slag + 
gravel and Portland cement + soil-aggregate. With regard to Hot Mix Asphalt surface types, there are draining (PA-12) and discontinuous (F-10) surface layer pavements or semi-dense mix pavements (S-12, S-20). Some sections have 3 layers, surface, intermediate and base, and others only surface and base, depending on the total thickness of HMA section. For intermediate and base layers, semi-dense mix pavements or thick HMA (G-20 and G-25) were employed. All these HMA types are refereed to Spanish rules (Ministerio de Fomento 2003). IRI data from these highways have been employed in the analysis until maintenance or rehabilitation treatment is carried out. The aim of the research is to analyse IRI performance without any measure on the surface. When a treatment is conducted, data from next survey are not employed.

\subsection{Traffic data processing}

Although having the same pavement section, it does not mean that all the length of each highway is under the same quantity of loads. Since there are some intersections in the alignment, different traffic volume is considered for each stretch. Regional Government of Biscay has collected traffic volume data in its road network since late 80's. Therefore it is possible to know the Average Daily Traffic (ADT) volume and the percentage of heavy traffic, but without no distinction on heavy vehicles categories (trucks types, buses, recreational vehicles) and does not classify axle weights. Only vehicles with a total weight above $3.500 \mathrm{~kg}$ are considered as heavy vehicles.

On the other hand, in some selected highways, there were some data lacks due to the fact that after opening a new highway, counts cannot be ready. In these cases, using the first year ADT volume data of the road, previous volumes have been estimated supposing a $2 \%$ increase rate of global traffic and maintaining the first known year's heavy traffic percentage. This rate has been usual during 1995 - 2005 period in the road network of Biscay. Hence, it is not possible to estimate usually employed heavy traffic factors, such as Equivalent Single-Axle Load (ESAL) (Odoki and Kerali 2000). Consequently, only total heavy traffic volume has been considered. For this purpose, it has calculated the proportion of volume in the road in the year it was constructed taking into account when it was open to traffic, which is an available data. Since it is not know when IRI data were collected, it has supposed that it was carried out in the middle of the indicated year (2000, 2004, 2007 or 2011). Normally these data collections were made in spring or in autumn, when values are supposed to be realer, so an average point of time has been estimated.

\subsection{Climate and subgrade data processing}

In some proposed IRI performance models, a Site Factor (SF) is included (Equations 1, 2 and 3) (AASHTO 2008). Since the extension of the territory of Biscay is reduced, only 2.217 $\mathrm{km}^{2}$, and Atlantic climate is predominant, it has been considered that the climatic influence is homogeneous in all the area. Annual average rainfall is $1.200 \mathrm{~mm}$, with small variations in the territory. So, all roads are exposed to the same climatic conditions. 
Perera and Kohn (2001) concluded that the effect of the subgrade conditions at a site can be not relevant if a pavement is designed "correctly" for these parameters. Since the highways in Spain are projected according the same regulations (Ministerio de Obras Públicas y Urbanismo 1989; Ministerio de Fomento 2003), climatic conditions and material properties are always taken into account. Consequently, no subgrade factors have been considered in IRI performance models.

\section{IRI PERFOMANCE MODELS}

All IRI measures taken every $100 \mathrm{~m}$ in each highway have been associated with two of the most used factors to forecast IRI performance: age (Figure 2) and heavy traffic volume (Figure 3).

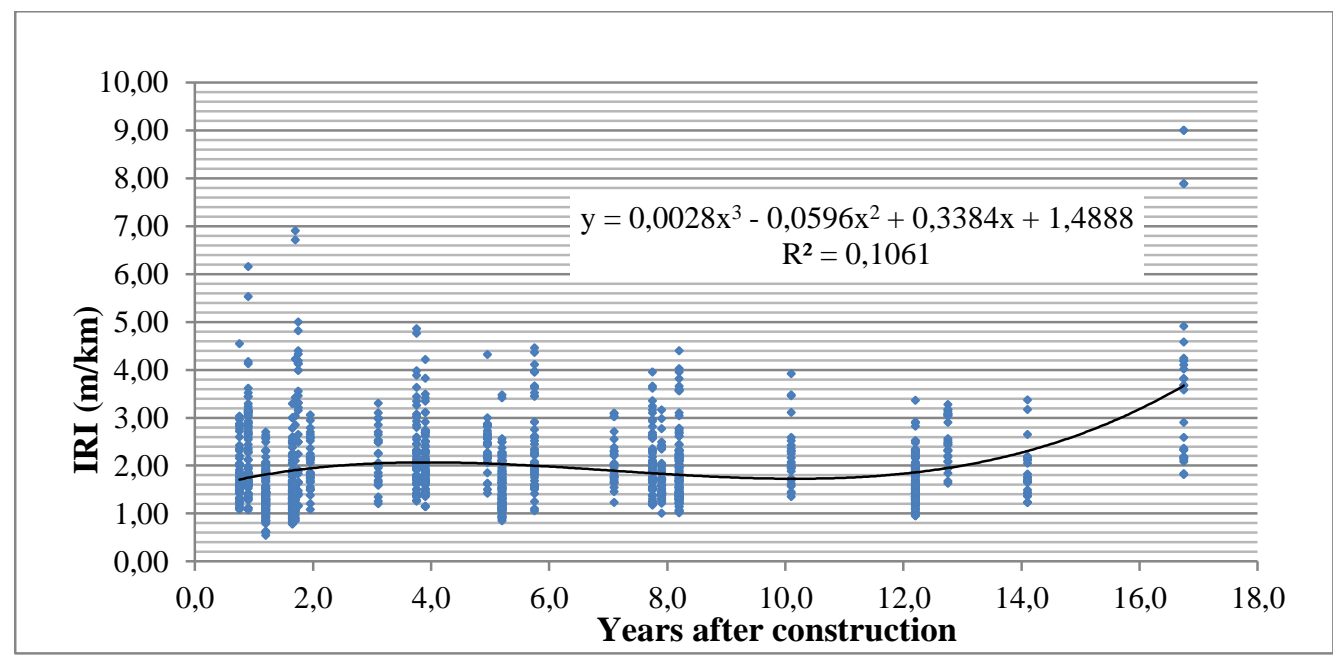

Figure 2 - IRI - Age graphic and tendency equation considering all the selected data.

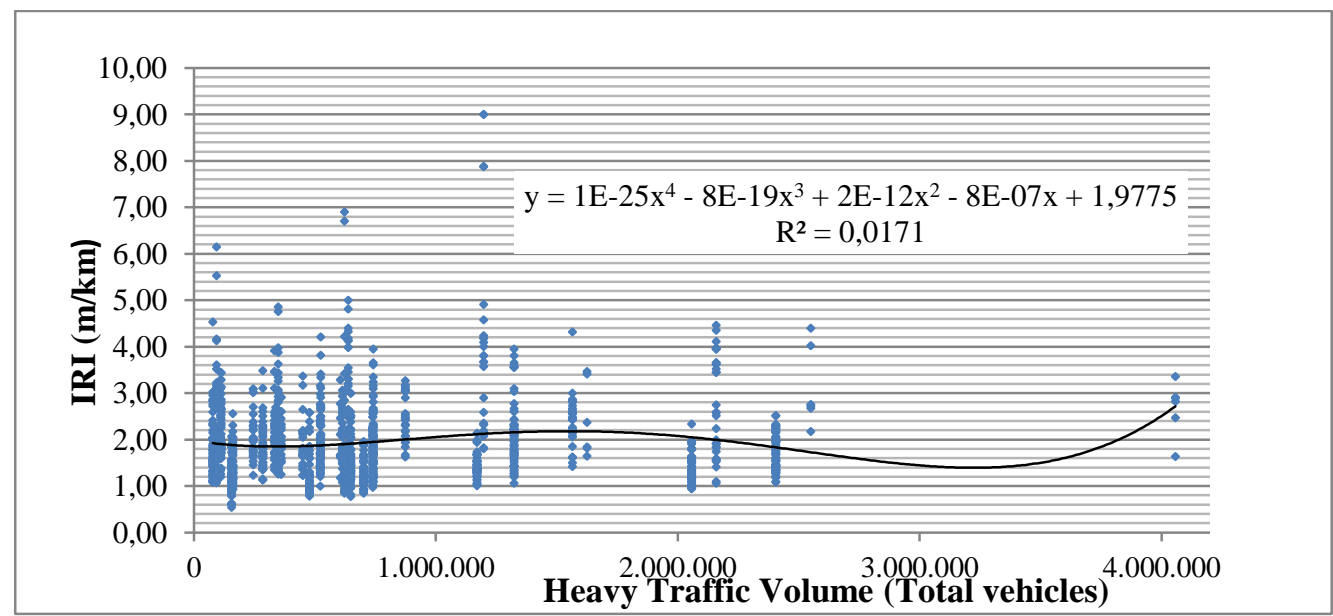

Figure 3 - IRI - Heavy Traffic Volume graphic and tendency equation considering all the selected data

As it can be observed, both tendency equations increase their estimated value with high independent variable values, but there are some areas where IRI value decreases. Obviously, 
this is not feasible since IRI values always get worse with time or with more traffic loads. Hence, average IRI values, and their standard variations, for each road section have been calculated instead of using all the available data together (Table 6).

\begin{tabular}{|c|c|c|c|c|c|c|c|}
\hline Highway & Initial PK & Final PK & Year & Side & $\begin{array}{c}\text { IRI } \\
\text { value }\end{array}$ & $\begin{array}{c}\text { SD of } \\
\text { IRI }\end{array}$ & $\begin{array}{c}\text { Pavement } \\
\text { type }\end{array}$ \\
\hline BI-635 & $34+0300$ & $37+0280$ & 2004 & Right & 1,906 & $\overline{00,690}$ & Semi-rigid \\
\hline BI-635 & $34+0300$ & $37+0280$ & 2004 & Left & 1,794 & 0,554 & Semi-rigid \\
\hline BI-635 & $34+0060$ & $37+0349$ & 2007 & Right & 2,225 & 0,751 & Semi-rigid \\
\hline BI-635 & $34+0060$ & $34+0159$ & 2007 & Left & 2,214 & 0,790 & Semi-rigid \\
\hline BI-635 & $34+0060$ & $37+0470$ & 2011 & Right & 2,045 & 0,623 & Semi-rigid \\
\hline BI-635 & $34+0060$ & $37+0470$ & 2011 & Left & 2,036 & 0,683 & Semi-rigid \\
\hline BI-2522 & $23+0820$ & $25+0120$ & 2000 & Right & 2,387 & 0,543 & Semi-rigid \\
\hline BI-2522 & $23+0820$ & $25+0120$ & 2000 & Left & 2,049 & 0,573 & Semi-rigid \\
\hline BI-2522 & $23+0820$ & $25+0120$ & 2004 & Right & 2,221 & 0,441 & Semi-rigid \\
\hline BI-2522 & $23+0820$ & $25+0120$ & 2004 & Left & 1,972 & 0,541 & Semi-rigid \\
\hline BI-2522 & $23+0790$ & $25+0099$ & 2007 & Right & 2,248 & 0,558 & Semi-rigid \\
\hline BI-2522 & $23+0790$ & $25+0099$ & 2007 & Left & 2,155 & 0,728 & Semi-rigid \\
\hline BI-2522 & $23+0760$ & $25+0170$ & 2011 & Right & 1,994 & 0,544 & Semi-rigid \\
\hline BI-2522 & $23+0760$ & $25+0170$ & 2011 & Left & 1,753 & 0,444 & Semi-rigid \\
\hline $\mathrm{N}-240$ & $30+0250$ & $32+0020$ & 2004 & Right & 2,035 & 0,437 & Flexible \\
\hline $\mathrm{N}-240$ & $30+0250$ & $32+0020$ & 2004 & Left & 2,023 & 0,538 & Flexible \\
\hline $\mathrm{N}-240$ & $30+0230$ & $32+0009$ & 2007 & Right & 2,383 & 0,364 & Flexible \\
\hline $\mathrm{N}-240$ & $30+0230$ & $32+0009$ & 2007 & Left & 2,464 & 0,624 & Flexible \\
\hline BI-625 & $351+0370$ & $352+0630$ & 2000 & Right & 1,787 & 0,274 & Flexible \\
\hline BI-625 & $351+0370$ & $352+0630$ & 2000 & Left & 2,271 & 0,391 & Flexible \\
\hline BI-625 & $351+0370$ & $352+0629$ & 2007 & Right & 2,351 & 0,490 & Flexible \\
\hline BI-625 & $351+0370$ & $352+0629$ & 2007 & Left & 2,675 & 0,437 & Flexible \\
\hline BI-625 & $351+0370$ & $352+0620$ & 2011 & Right & 4,106 & 2,167 & Flexible \\
\hline BI-625 & $351+0370$ & $351+0470$ & 2011 & Left & 3,707 & 1,946 & Flexible \\
\hline BI-732 & $50+0030$ & $51+0181$ & 2007 & Right & 2,643 & 1,162 & Semi-rigid \\
\hline BI-732 & $50+0030$ & $51+0181$ & 2007 & Left & 2,922 & 1,202 & Semi-rigid \\
\hline BI-732 & $50+0030$ & $51+0340$ & 2011 & Right & 2,637 & 0,980 & Semi-rigid \\
\hline BI-732 & $50+0030$ & $50+0130$ & 2011 & Left & 2,727 & 1,127 & Semi-rigid \\
\hline $\mathrm{N}-636$ & $40+0430$ & $41+0640$ & 2000 & Right & 1,141 & 0,443 & Flexible \\
\hline $\mathrm{N}-636$ & $44+0080$ & $44+0330$ & 2000 & Right & 2,440 & 0,184 & Flexible \\
\hline $\mathrm{N}-636$ & $41+0650$ & $42+0210$ & 2000 & Right & 1,142 & 0,184 & Flexible \\
\hline $\mathrm{N}-636$ & $42+0220$ & $44+0070$ & 2000 & Right & 1,359 & 0,368 & Flexible \\
\hline $\mathrm{N}-636 \mathrm{~d}$ & $41+0680$ & 150 & 2000 & Right & 1,110 & 0,294 & Flexible \\
\hline $\begin{array}{l}\mathrm{N}-636 \mathrm{~d} \\
\end{array}$ & $42+$ & 250 & 2000 & Right & 1,625 & 0,330 & Flexible \\
\hline $\mathrm{N}-636$ & $40+0430$ & $41+$ & 2000 & Left & 1,311 & 0,463 & xible \\
\hline $\mathrm{N}-636$ & $44+0080$ & $44+0330$ & 2000 & Left & 2,573 & 0,062 & Flexible \\
\hline $\mathrm{N}-636$ & $41+0650$ & $42+0210$ & 2000 & Left & 1,343 & 0,233 & Flexible \\
\hline $\mathrm{N}-636$ & $42+0220$ & $44+0070$ & 2000 & Left & 1,350 & 0,299 & Flexible \\
\hline $\mathrm{N}-636 \mathrm{~d}$ & $41+0680$ & $42+0250$ & 2000 & Left & 1,307 & 0,153 & Flexible \\
\hline $\mathrm{N}-636 \mathrm{~d}$ & $42+0440$ & $43+0870$ & 2000 & Left & 1,576 & 0,370 & Flexible \\
\hline $\mathrm{N}-636$ & $40+0430$ & $41+0640$ & 2004 & Right & 1,344 & 0,316 & Flexible \\
\hline $\mathrm{N}-636$ & $44+0080$ & $44+0370$ & 2004 & Right & 2,357 & 0,745 & Flexible \\
\hline $\mathrm{N}-636$ & $41+0650$ & $42+0210$ & 2004 & Right & 1,127 & 0,216 & exible \\
\hline $\mathrm{N}-636$ & $42+0220$ & $44+0070$ & 2004 & Right & 1,479 & 0,441 & Flexible \\
\hline N-636d & $41+0700$ & $42+0170$ & 2004 & Right & 1,243 & 0,265 & Flexible \\
\hline N-636d & $42+0360$ & $43+0890$ & 2004 & Right & 1,99824 & 0,225 & Flexible \\
\hline $\mathrm{N}-636$ & $40+0430$ & $41+0640$ & 2004 & Left & 1,354 & 0,343 & Flexible \\
\hline $\mathrm{N}-636$ & $44+0080$ & $44+0370$ & 2004 & Left & 2,497 & 0,748 & Flexible \\
\hline $\mathrm{N}-636$ & $41+0650$ & $42+0210$ & 2004 & Left & 1,290 & 0,112 & Flexible \\
\hline $\mathrm{N}-636$ & $42+0220$ & $44+0070$ & 2004 & Left & 1,497 & 0,435 & Flexible \\
\hline $\mathrm{N}-636 \mathrm{~d}$ & $41+0700$ & $42+0070$ & 2004 & Left & 1,440 & 0,182 & Flexible \\
\hline $\mathrm{N}-636 \mathrm{~d}$ & $42+0260$ & $43+0890$ & 2004 & Left & 1,639 & 0,425 & Flexible \\
\hline $\mathrm{N}-636$ & $40+0420$ & $41+0639$ & 2007 & Right & 1,447 & 0,287 & Flexible \\
\hline $\mathrm{N}-636$ & $44+0070$ & $44+0369$ & 2007 & Right & 3,713 & 0,719 & Flexible \\
\hline $\mathrm{N}-636$ & $41+0640$ & $42+0209$ & 2007 & Right & 1,323 & 0,076 & Flexible \\
\hline $\mathrm{N}-636$ & $42+0210$ & $44+0069$ & 2007 & Right & 2,540 & 0,815 & Flexible \\
\hline $\mathrm{N}-636 \mathrm{~d}$ & $41+0620$ & $42+0081$ & 2007 & Right & 1,363 & 0,295 & Flexible \\
\hline $\begin{array}{l}\mathrm{N}-636 \mathrm{~d} \\
\end{array}$ & $42+0280$ & $43+0801$ & 2007 & Right & 1,99824 & 0,322 & Flexible \\
\hline $\mathrm{N}-636$ & $40+0420$ & $41+0639$ & 2007 & Left & 1,551 & 0,195 & Flexible \\
\hline $\mathrm{N}-636$ & $44+0070$ & $44+0369$ & 2007 & Left & 2,540 & 0,257 & Flexible \\
\hline $\mathrm{N}-636$ & $41+0640$ & $42+0209$ & 2007 & Left & 1,313 & 0,077 & Flexible \\
\hline
\end{tabular}




\begin{tabular}{|c|c|c|c|c|c|c|c|}
\hline N-636 & $42+0210$ & $44+0069$ & 2007 & Left & 2,269 & 0,621 & Flexible \\
\hline $\mathrm{N}-636 \mathrm{~d}$ & $41+0620$ & $42+0081$ & 2007 & Left & 1,460 & 0,172 & Flexible \\
\hline N-636d & $42+0280$ & $43+0801$ & 2007 & Left & 1,588 & 0,306 & Flexible \\
\hline N-636 & $40+0440$ & $41+0660$ & 2011 & Right & 1,474 & 0,389 & Flexible \\
\hline N-636 & $44+0090$ & $44+0390$ & 2011 & Right & 2,727 & 0,184 & Flexible \\
\hline N-636 & $41+0660$ & $42+0230$ & 2011 & Right & 1,212 & 0,109 & Flexible \\
\hline N-636 & $42+0230$ & $44+0090$ & 2011 & Right & 1,602 & 0,337 & Flexible \\
\hline $\mathrm{N}-636 \mathrm{~d}$ & $41+0680$ & $42+0130$ & 2011 & Right & 1,318 & 0,274 & Flexible \\
\hline N-636d & $42+0330$ & $43+0860$ & 2011 & Right & 1,979 & 0,311 & Flexible \\
\hline N-636 & $40+0440$ & $41+0660$ & 2011 & Left & 1,474 & 0,329 & Flexible \\
\hline N-636 & $44+0090$ & $44+0390$ & 2011 & Left & 2,637 & 0,728 & Flexible \\
\hline N-636 & $41+0660$ & $42+0230$ & 2011 & Left & 1,503 & 0,084 & Flexible \\
\hline N-636 & $42+0230$ & $41+0580$ & 2011 & Left & 1,723 & 0,410 & Flexible \\
\hline N-636d & $41+0680$ & $42+0130$ & 2011 & Left & 1,511 & 0,244 & Flexible \\
\hline $\mathrm{N}-636 \mathrm{~d}$ & $42+0330$ & $43+0860$ & 2011 & Left & 1,634 & 0,312 & Flexible \\
\hline $\mathrm{N}-240$ & $19+0090$ & $24+0040$ & 2011 & Right & 1,438 & 0,493 & Semi-rigid \\
\hline $\mathrm{N}-240$ & $19+0090$ & $24+0040$ & 2011 & Left & 1,680 & 0,577 & Semi-rigid \\
\hline BI-633 & $5757+0070$ & 59+0540 & 2004 & Right & 2,295 & 1,150 & Flexible \\
\hline BI-633 & $57+0040$ & $59+0549$ & 2007 & Right & 1,710 & 0,458 & Flexible \\
\hline BI-633 & $57+0020$ & $59+0530$ & 2011 & Right & 1,645 & 0,394 & Flexible \\
\hline BI-633 & $57+0070$ & $59+0540$ & 2004 & Left & 2,307 & 1,016 & Flexible \\
\hline BI-633 & $57+0040$ & $59+0549$ & 2007 & Left & 1,960 & 0,444 & Flexible \\
\hline BI-633 & $57+0020$ & $59+0530$ & 2011 & Left & 1,804 & 0,488 & Flexible \\
\hline BI-2405 & $65+0000$ & $66+0950$ & 2011 & Right & 1,917 & 1,379 & Semi-rigid \\
\hline BI-2405 & $65+0000$ & $66+0950$ & 2011 & Left & 1,797 & 1,373 & Semi-rigid \\
\hline BI-633 & $49+0150$ & $50+0550$ & 2004 & Right & 2,399 & 0,520 & Flexible \\
\hline BI-633 & $49+0150$ & $50+0550$ & 2004 & Left & 2,311 & 0,627 & Flexible \\
\hline BI-633 & $49+0190$ & $50+0599$ & 2007 & Right & 2,541 & 0,547 & Flexible \\
\hline BI-633 & $49+0190$ & $50+0599$ & 2007 & Left & 2,466 & 0,499 & Flexible \\
\hline
\end{tabular}

Table 6 - Average IRI and Standard Deviation values of each road section

It can be observed in Table 6 that in some roads, IRI values get better with time. These values are marked in red and are considered wrong data. It is illogical to obtain better values after time and heavy vehicles have passed. Some explanations for these data are:

- Seasonal variation during data collection affecting the values.

- Different IRI measurement tool in different surveys.

- Present Pavement Management System has not recorded really conducted maintenance and rehabilitation.

In BI-635 highway better data are obtained in 2011, which proposes that some rehabilitation has been carried out. In BI-2522 highways spurious data are obtained from the second data survey, indicating something anomalous. BI-732 highway gets better values in the second campaign. N-636 highway had a specific maintenance campaign, concluding that some treatments were conducted without being recorded in the PMS. There are also improvements in IRI values in BI-633 values in Ondarroa. In 3 of the 5 semi-rigid highways anomalous values appeared. In flexible pavements, only in BI-633 obtain an improvement. In the case of $\mathrm{N}-636$ is considered that not all the maintenance was registered.

As a result, average IRI section values that do not get worse than the previous one (marked in red) are considered erroneous and have been canceled.

\subsection{IRI performance models for each pavement type}

After cancelling the anomalous data, values have been separately considered. For semi-rigid pavements, results and best adjusted equation still have zones where IRI values get better 
after time and more traffic volume, as Figure 4 and 5 show.

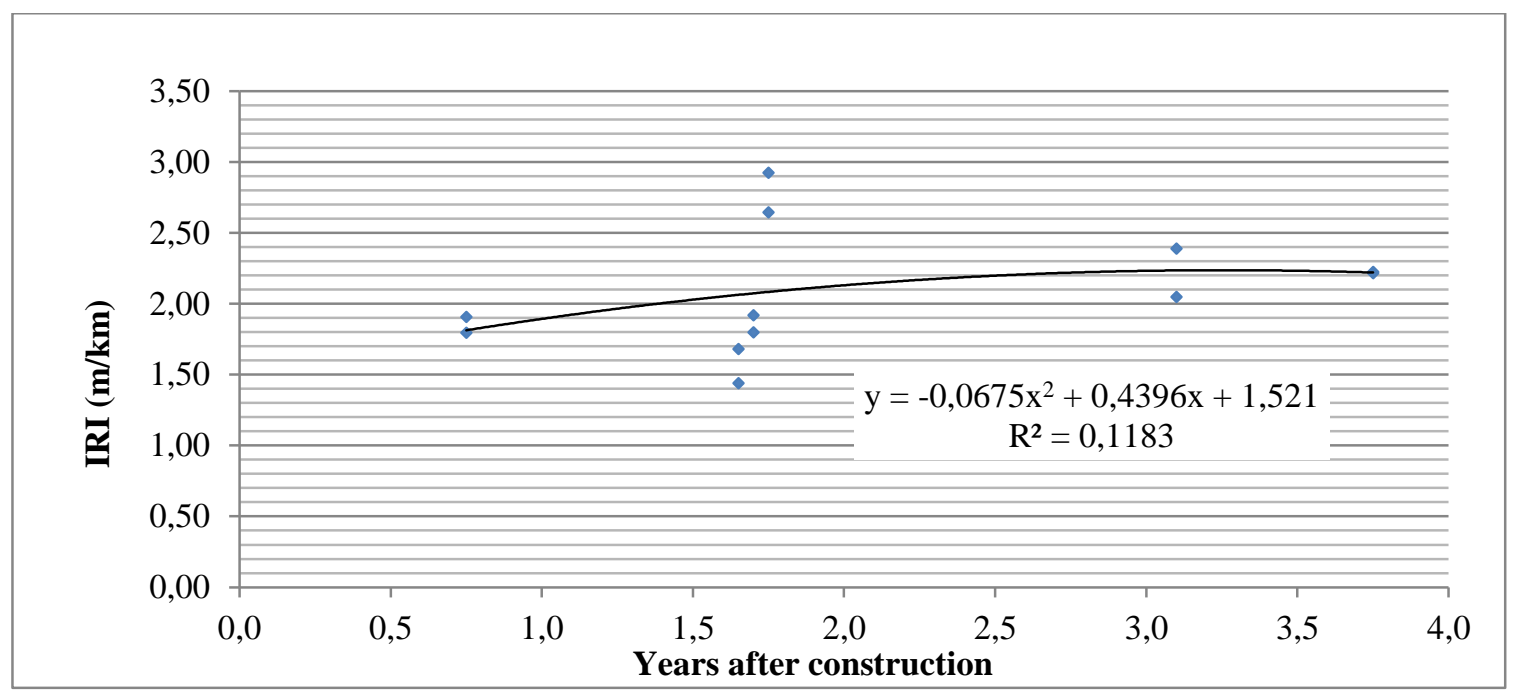

Figure 4 - IRI - Age graphic and tendency equation for semi-rigid pavements

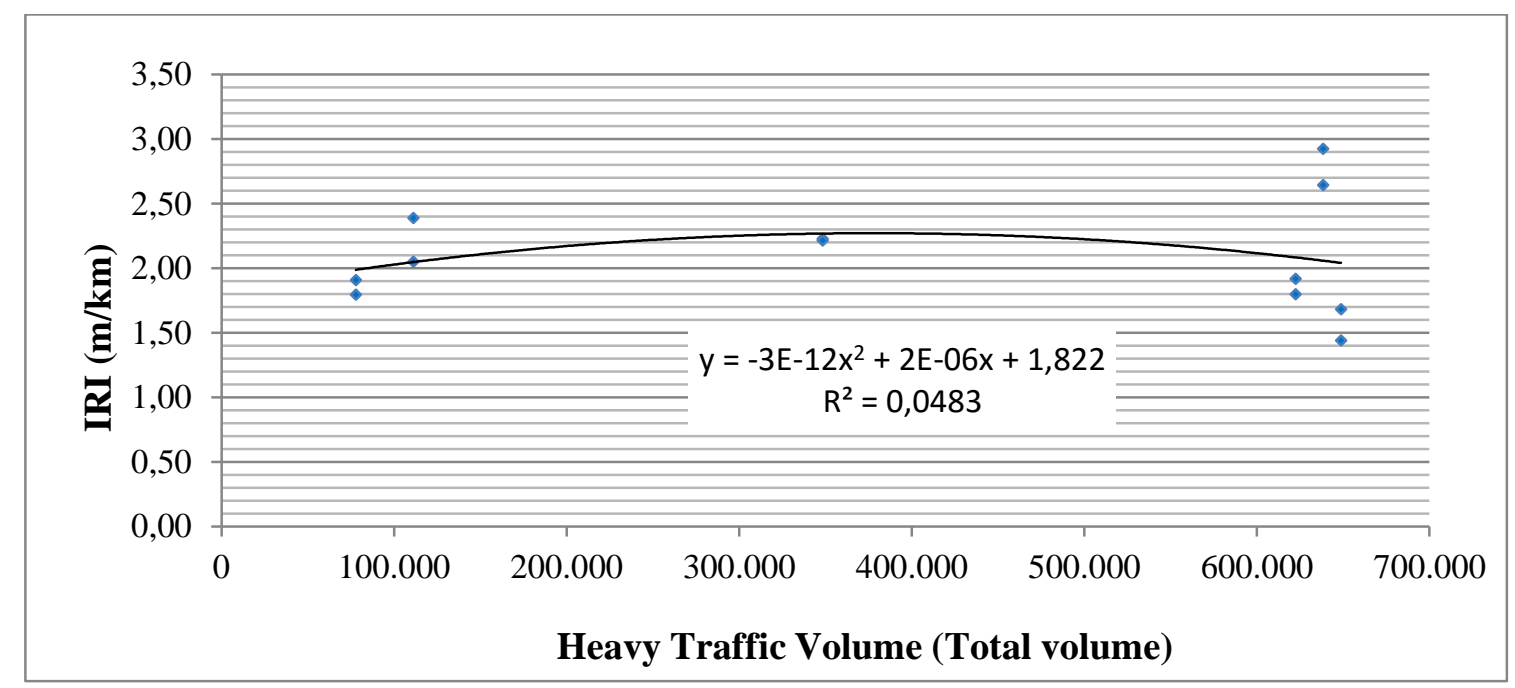

Figure 5 - IRI - Heavy Traffic Volume graphic and tendency equation for semi-rigid pavements

Consequently, when analyzing semi-rigid pavements other parameters must be taken into account. As the MEPDG proposes (AASHTO 2008), there is still a need of calibrating semirigid pavement

For flexible pavements, data analysis has show coherence (Figure 6 and 7), a higher level of correlation between data and, consequently some IRI performance equations are proposed (Equations 4 and 5). 


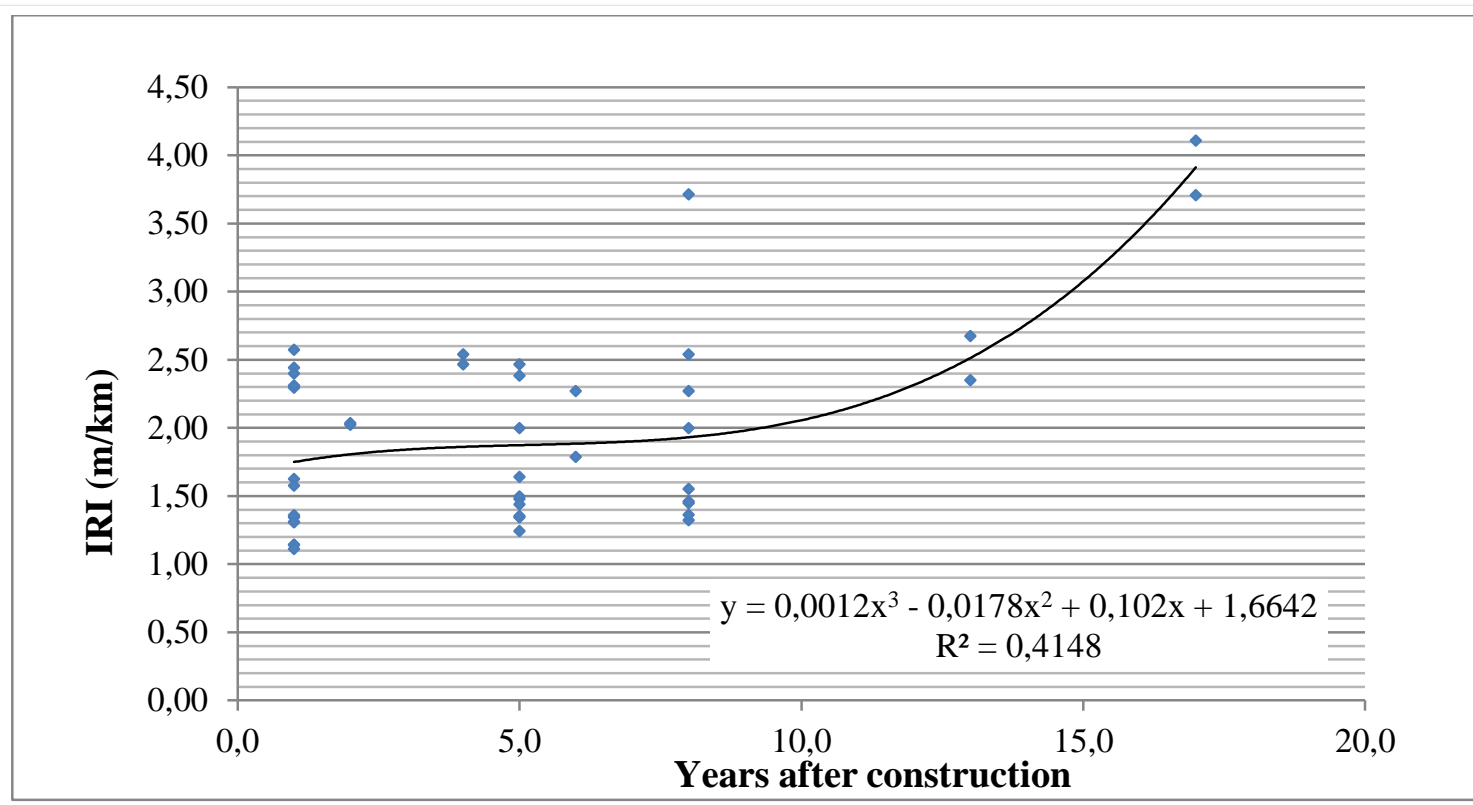

Figure 6 - IRI - Age graphic and tendency equation for flexible pavements

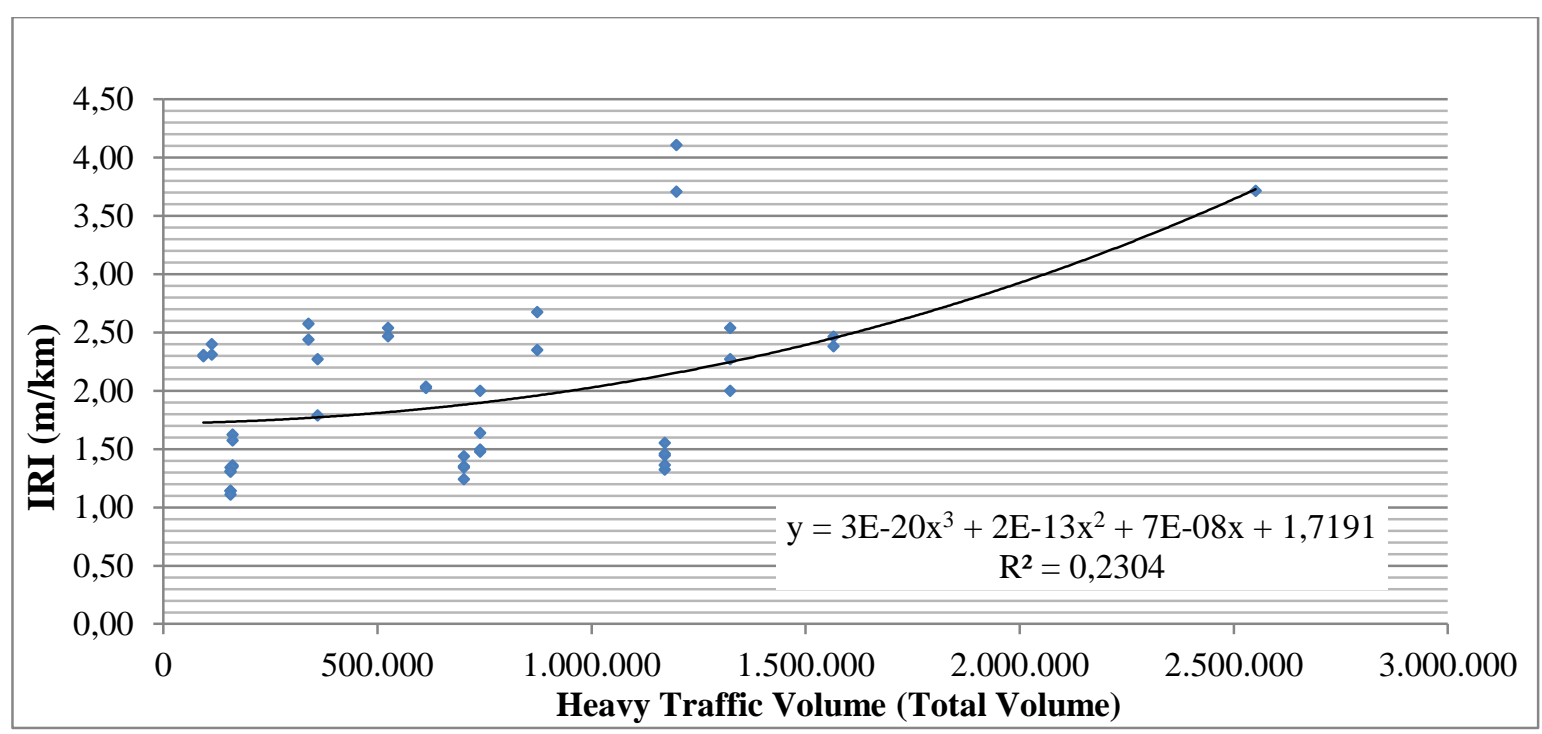

Figure 7 - IRI - Heavy Traffic Volume graphic and tendency equation for flexible pavements

$$
\begin{gathered}
I R I=0,0012 \cdot A_{g} e^{3}-0,0178 \cdot A g e^{2}+0,102 \cdot A g e+1,1662 \\
I R I=3 \cdot 10^{-20} \cdot H T V+2 \cdot 10^{-13} \cdot H T V+7 \cdot 10^{-8} \cdot H T V+1,7191
\end{gathered}
$$

Where IRI is the estimated value for IRI, Age is the years since road construction and HTV is the total heavy traffic volume that has passed through the section or estimation. Influence of surface pavement type has been also analyzed but not better correlation has been found. These equations ( 4 and 5) can be only applied when no treatment has been carried out in the road. They represent the natural IRI performance without maintenance. The values for IRI after the road is in service would be 1,162 (Eq. 4) and 1,7191 (Eq. 5), which are accepted 
values according to Spanish regulations about new constructed road, shown in Table 7 (Ministerio de Fomento, 2003)

\begin{tabular}{|c|c|c|c|}
\hline \multirow{2}{*}{$\begin{array}{c}\text { Percentage of } \\
\text { hectometers }(\%)\end{array}$} & \multicolumn{2}{|c|}{ Layer type } & $\begin{array}{c}\text { Other } \\
\text { bituminous } \\
\text { layers }\end{array}$ \\
\cline { 2 - 3 } & \multicolumn{2}{|c|}{ Road classification } & $<2,0$ \\
\cline { 2 - 3 } & Freeways & Other highways & $<2,5$ \\
\hline 50 & $<1,5$ & $<1,5$ & $<3,0$ \\
\hline 80 & $<1,8$ & $<2,0$ & $<2,5$ \\
\hline
\end{tabular}

Table 7 - IRI ( $\mathrm{dm} / \mathrm{hm})$ for newly constructed roads

\section{CONCLUSIONS}

IRI performance models are useful tools for Pavement Management Systems for forecasting future road conditions based on current information and, consequently, give priority to maintenance strategies all over a road network. In this paper recently constructed low and medium traffic two lane highways in the province of Biscay have been analyzed so as to have IRI performance models that could be applied in the PMS that the Regional Government of Biscay is developing. Only new design roads have been selected, with the aim of not taking into consideration previously existing layers and data until a treatment is made on the surface have been considered. Despite the fact that each road has the same pavement section, different heavy traffic volumes have been considered, dividing the total lengths in stretches. Flexible and semi-rigid pavement sections were used.

Since exact quantity of Equivalent Single-Axle Load cannot be determined and climate conditions and average rainfall are homogeneous over the entire small extension of the territory of Biscay, only two parameters have been considered for IRI models: years from construction and total heavy traffic volume. Regression models have been calculated with all data, but incoherent results have found, indicating that after time or heavy vehicles IRI values get better. The average IRI value and its standard deviation of each considered section has been calculated and in some cases, values become better after time. Some reasons have been proposed: seasonal influence, different IRI measuring tool or not recorded maintenance or rehabilitation treatment has been applied. After removing these spurious data, flexible and semi-rigid pavements have been analyzed separately. In semi-rigid pavements no conclusion has been reached, as results continue being illogical. More research in this kind of pavement is proposed. For flexible pavement, values show coherence and some equations have been proposed for predicting future IRI values using age and total heavy traffic volume parameters. No influence of surface layer in flexible pavements has been also confirmed.

\section{ACKNOLEDGEMENTS}

This research has been possible due to the agreement between the University of the Basque Country and the Regional Government of Biscay, which allows to Heriberto Pérez-Acebo to 
handle, use, analyze and research the Pavement Management System data.

\section{REFERENCES}

AASHTO (2008). Mechanistic-Empirical Pavement Design Guide, Interim Edition: A Manual of Practice. American Association of State Highway and Transportation Officials, Washington, D.C.

AASHTO (2011). AASHTOWare ${ }^{\circledR}$ DARWin-ME ${ }^{\mathrm{TM}}$ v. 1.0 mechanistic-empirical pavement design software. American Association of State Highway and Transportation Officials, Washington, DC.

ARCHONDO-CALLAO, R.S. and FAIZ, A. (1994). Estimating vehicle operation costs. Technical paper No. 234. International Bank for Reconstruction and Development, World Bank, Washington, DC, USA

HAAS, R., HUDSON, W.R., and ZANIEWSKI, J. (1994). Modern pavement management. Krieger Publishing, Malabar, Florida.

MADANAT, S., NAKAT, Z., FARSHIDI, F., SATHAYE, N. and HARVEY, J. (2005). Development of empirical-mechanistic pavement performance models using data from Washington State PMS database. Research Report UCPRC-RR-2005-05

MEEGODA, J.N. and GAO, S. (2014). Roughness Progression Model for Asphalt Pavements Using Long-Term Pavement Performance Data. Journal of Transportation Engineering 140(8), pp. 04014037.

MINISTERIO DE OBRAS PÚBLICAS Y URBANISMO (1989). Norma 6.1 y 6.2-IC Secciones de Firmes. Dirección General de Carreteras. Gobierno de España

MINISTERIO DE FOMENTO (2003). Norma 6.1-IC Secciones de Firmes. Secretaría de Estado de Planificación e Infraestructura. Secretaría General de Infraestructuras. Dirección General de Carreteras. Gobierno de España

MOLENAAR, A.A.A. (2003). Pavement performance evaluation and rehabilitation design. MAIREPAV 2003, proceeding, Guimaraes, Portugal

NCHRP (NATIONAL COOPERATIVE HIGHWAY RESEARCH PROGRAM) (2004). Guide for the mechanistic-empirical design for new and rehabilitated pavement structures. Final Report 1-37A. Transportation Research Board, Washington DC.

ODOKI, J.B. and KERALI, H.G.R. (2000). Analytical Framework and Model Descriptions. 
Highway Development \& Management (HDM-4) Volume 4. The World Road Association (PIARC), Washington, DC

PATERSON, W.D.O. (1987). Road Deterioration and maintenance effects: Models for planning and management. John Hopkins University Press, Baltimore, MD.

PERERA, R.W., and KOHN, S.D. (2001). LTPP data base analysis: Factors affecting NCHRP Web Document 40.

PROZZI, J.A. and MADANAT, S.M. (2004). Development of pavement performance models by combining experimental and field data. Journal of Infrastructure systems 10(1), pp. 9-22.

SAYERS, M.W. (1995). On the calculation of IRI from longitudinal road profile. $74^{\text {th }}$ Annual Meeting on Transportation Research Board, TRB'95, Paper No. 950842. Washington, DC, USA

SAYERS, M.W., GILLESPIE, T.D. and PATERSON, W.D. (1986). Guidelines for the conduct and calibration of road roughness measurements. World Bank Technical Paper 46, The World Bank, Washington, DC, USA.

WEN, H. (2011). Design factors affecting the initial roughness of asphalt pavements. International Journal of Pavement Research and Technology, 4(5), pp. 268-273. 